\title{
O REALISMO TENSO EM AQUARIUS: ASPECTOS UTÓPICOS E POLÍTICOS NA NARRATIVA E NA IMAGEM FÍLMICA
}

\author{
THE TENSE REALISM IN AQUARIUS: UTOPICAL AND POLITICAL \\ ASPECTS OF IMAGE IN NARRATIVE FILM
}

Volmir Cardoso Pereira'

RESUMO: Este texto elabora uma crítica sobre o filme Aquarius, dirigido por Kleber Mendonça Filho e lançado em 2016, destacando aspectos de conteúdo e forma que estabelecem, segundo nossa hipótese, características do que aqui vamos chamar de realismo tenso. Tal conceito visa a compreender a poética do filme como uma construçăo narrativa que se aproxima do realismo formal, cujas fontes remontam ao romance literário do século XIX. Ao observar a influência da literatura realista sobre a linguagem do cinema, convém ressaltar que Aquarius apresenta traços do Neorrealismo Italiano e do Cinema Novo, ao mesmo tempo em que se apropria criticamente de estratégias contemporâneas do thriller de suspense na açâo dramática e no encadeamento cênico. Por fim, observando a tensâo que se estabelece no plano de conteúdo, podemos notar que ela também se expande para o plano de expressăo, provocando uma quebra de expectativas que visa a problematizar os estereótipos imagéticos e narrativos que povoam o imaginário do espectador contemporâneo. Assim, observando a narrativa fílmica, pretendemos mostrar como ela apresenta aspectos políticos e utópicos inscritos em forma e conteúdo, ao discutir o tema da reificaçăo social no cenário brasileiro atual.

Palavras-chave: Crítica materialista; Aquarius; Realismo tenso.

ABSTRACT: This article elaborates on a critical analysis about the film Aquarius, directed by Kleber Mendonça Filho and released in 2016. The film highlights aspects of content and form that establish, according to our hypothesis, the characteristics of what we call "tense realism". This concept aims to understand the poetics of the film as a narrative construction that approaches formal realism whose sources go back to the literary novel of the nineteenth century. When observing the influence of the realistic literature on the language of cinema, it is necessary to emphasize that Aquarius presents traces of Italian Neo-Realism and "Cinema Novo", at the same time that critically appropriates the contemporary strategies of thriller movies in the dramatic action and in chain of events. Finally, observing the tension that is established in the

Doutor em Letras/Estudos literários pela UEL - Universidade Estadual de Londrina. Coordenador e Professor do Curso de Letras Português/Espanhol da UEMS - Universidade Estadual de Mato Grosso do Sul, campus de Campo Grande. Pesquisador de Literatura, Cinema e sociedade: diálogos críticos sobre o contemporâneo. 
content plane, we can see that it also expands to the expression plane, provoking a breach of expectations that problematize the imagery and narrative of stereotypes that was in the imagination of the contemporary spectator. Thus, observing the film narrative, we intend to show how it presents political and utopian aspects inscribed in form and content, when discussing the theme of social reification in the current Brazilian scenario.

Keywords: Critical Materialist Theory; Aquarius; Tense Realism.

\section{Introdução}

A boa recepçâo crítica aos dois longas-metragens de Kleber Mendonça Filho - O Som ao Redor (2012) e Aquarius (2016 ) - ressalta uma nova possibilidade de representaçăo social que se articula após o período da Retomada: o realismo cinematográfico que procura, por estratégias narrativas inusitadas, ir à busca de narrar a naçáo novamente. Segundo Oricchio (2003), o chamado Cinema da Retomada (compreendido entre os anos 1990 e início dos 2000), afeito ao paradigma da diversidade, ${ }^{2}$ ainda que tenha se preocupado em apresentar temáticas sociais, quase sempre as colocava como pano de fundo, destacando o drama afetivo-familiar (por vezes, próximo ao melodrama) ou promovia uma espetacularizaçâo das mazelas sociais, valendo-se do thriller de açâo, policial e de suspense. Mesmo temas eminentemente sociais como a violência urbana, foram registrados a partir de gêneros mais próximos à narratividade hollywoodiana. Basta pensar em filmes como Açâo entre Amigos (1998), de Beto Brant, Cidade de Deus (2002), de Fernando Meirelles, Contra Todos (2003), entre muitos outros que se valeram, com maior ou menor grau de criaçâo estética, das fórmulas pósmodernas do mercado cinematográfico mundializado. Como afirma Nagib (2006): “[...] a produçâo brasileira recente transcende o projeto nacional do cinema novo e se irmana a correntes do cinema moderno, pós-moderno e comercial mundial, tornando-se beneficiária e contribuinte de uma nova estética cinematográfica transnacional" (p. 17).

A partir desse contexto, neste ensaio propomos uma leitura do filme Aquarius buscando destacar justamente suas diferenças em relaçăo à tônica da produçâo fílmica mais recente. Assim, buscamos afirmar os traços realistas que o definem, marcados por uma tensâo dramática durativa, forte o suficiente para elaborar na narrativa, uma representaçáo crítica da reificação social, gerando um efeito de estranhamento pelas imagens. Em nossa hipótese, tal estranhamento resulta da tensâo no plano de expressăo, a partir da qual se desenvolve concomitantemente um flerte e um rompimento com as estratégias esquemáticas do thriller e do melodrama contemporâneos. Desta feita, há no filme de Kleber Mendonça Filho uma poética que enforma o que aqui chamaremos de realismo tenso, marcando um importante momento do cinema brasileiro atual, no qual a representaçâo da

2 Ao observar a multiplicidade de temáticas e estilos na Retomada, o autor afirma: "essa variedade de oferta, que năo é apenas de gêneros, mas de estilos, pode ser entendida de outra forma. Ela refletiria também a típica fragmentaçấo mental dos anos 1990. Com o chamado 'fim das utopias', cada qual se sentiu liberado para estabelecer a própria agenda de prioridades." Ibid., p. 30. 
naçăo e suas implicaçōes políticas e utópicas coexistem com o deslumbramento imagético na pós-modernidade.

De modo geral, fazemos aqui um esforço para elaborar relaçôes entre narrativa e imagem a partir da teoria literária, cinematográfica e semiótica, vinculando-as a uma crítica materialista, para a qual as formas estéticas e os conteúdos culturais devem ser observados em relaçâo direta com suas condiçôes concretas de produçáo, seu momento histórico e as ideologias sociais que o revestem. Destarte, esse diálogo entre sociedade, história e obra artística guia-se primeiramente pela prerrogativa de que a forma estética deve ser analisada em sua complexidade dialética, năo sendo puro espelhamento da base material, nem ilustraçâo de uma tese sociológica. Daí a necessidade de primeiro se acercar de uma teoria da narrativa que possa servir de eixo comum para a análise do conteúdo, afinal, cinema e literatura desenvolveram historicamente um câmbio de experiências que, de um lado, definiu a própria linguagem cinematográfica e, por outro, ressoou na própria forma literária, capaz de assimilar posteriormente diversas estratégias narrativas advindas da montagem fílmica. Assim, a análise de um filme pode começar pela constataçăo mais geral de sua condiçáo enquanto narrativa:

\footnotetext{
O filme narrativo-dramático, a peça de teatro, o conto e o romance têm em comum uma questăo de forma que diz respeito ao modo de disposiçáo dos acontecimentos e açóes das personagens. Quem narra escolhe o momento em que uma informaçăo é dada e por meio de que canal isso é feito. Há uma ordem das coisas no espaço e no tempo vivido pelas personagens, e há o que vem antes e o que vem depois ao nosso olhar de espectadores, seja na tela, no palco ou no texto. (XAVIER, 2003, p. 64)
}

Por outro lado, será observando a especificidade da expressăo cinematográfica, sua potência específica enquanto linguagem audiovisual, que poderemos atribuir novos sentidos à própria narrativa, destacando os efeitos que as imagens produzem sobre o enunciatário pressuposto (espectador).

\section{0 realismo formal como problema histórico: narrativa, imagem e modos de representação.}

Definir o realismo formal como elemento estruturante em Aquarius exige, de antemâo, uma investigaçâo teórica e histórica sobre o que ainda pode ser considerada uma representaçâo realista nas condiçôes dadas à imagem na pós-modernidade. Primeiramente, cabe ressaltar a filiaçăo literária do realismo como modo de representaçấo que marcou a ascensâo burguesa como classe fundamental no século XIX. A crença no progresso e na técnica, enquanto ideologia dominante, imbuíram a arte literária de um compromisso social pautado pelo registro supostamente objetivo do real, como uma forma de desvendamento do mundo. Contudo, como é sabido, no decorrer do século XX, a partir das vanguardas modernistas, essa crença na representaçâo objetiva do real vai sendo duramente questionada. Um mundo em constante transformaçăo tecnológica, as grandes concentraçóes urbanas e, sobretudo, o horror de duas grandes guerras, vâo de certa forma, inviabilizando a narrativa realista, tornando-a inapropriada para comunicar os traumas coletivos e a fragmentaçăo, atomizaçâo e burocratizaçâo 
da vida cotidiana. Este é o diagnóstico dado pelos frankfurtianos, em especial, Theodor Adorno que, nos anos 1950, decreta o malfado de qualquer romance que busque comunicar uma experiência objetivamente, "pois contar algo significa ter algo especial a dizer, e justamente isso é impedido pelo mundo administrado, pela estandardizaçăo e pela mesmice" (ADORNO, 2003, p. 56). 0 experimentalismo modernista e a fragmentaçăo do narrador tradicional seriam a consequência direta desta consciência artística da incapacidade de se representar objetiva e diretamente a realidade. Contudo, é certo que o realismo persistiu, de algum modo, como forma ideológica amplamente desenvolvida pelas narrativas da cultura de massa, sendo a base da informatividade jornalística, dos best sellers, do romance policial, biográfico e, claro, do cinema. Na contemporaneidade, as tentativas de se recuperar esteticamente o realismo significa, por conseguinte, compreender que ele já năo corresponde a uma tomada direta e objetiva da realidade, mas antes um constataçáo de que o aparato perceptivo e nossa visăo de mundo, encontram-se condicionados pelos códigos da comunicaçăo massivomidiática. Haveria, portanto, uma persistência do realismo como forma estética, embora suas premissas estético-ideológicas tenham se alterado drasticamente. Nessa direçấo, Pellegrini (2009, p. 34) conclui:

[...] o realismo, saindo pela porta da frente, volta sempre pela dos fundos, como um modo - uma forma - de se impor ao sujeito como presença inescapável, representaçăo da existência concreta do mundo, mesmo como simulacro. [...] Volta despido de sua postura libertária dos primeiros tempos, de seu sentido coletivo, de sua intençâo de penetrar profundamente no reino dos objetos para devorá-los por dentro, [...] volta como sintoma e diagnóstico de um estado de coisas de alguma forma parecido com o momento em que ele eclodiu como necessidade histórica.

Se nos voltarmos para o cinema, observaremos, também, que a polêmica sobre o realismo năo foi menos complexa, sobretudo quando seus realizadores se preocuparam diretamente com o problema da legitimaçăo e consolidaçấo da linguagem cinematográfica como uma forma específica de arte. Em princípio, seria anacrônico e ingênuo definir o realismo cinematográfico como uma premissa formal dada pelo seu aparato técnico, como se bastasse justificar tal realismo imanente pelo próprio registro objetivo da câmera frente ao mundo. No entanto, tal perspectiva utópica remonta a André Bazin e à sua apologia da imagem-fato, capaz de atingir a especificidade e a potência da representaçăo cinematográfica: um registro direto do mundo, no qual a açăo dramática e a vontade de narrar imposta à câmera năo obliteram a complexidade da situaçáo (p. ext., o fenômeno) captada (BAZIN, 1991). Em sua teoria, filmes como Europa 51 (Rosselini), Umberto $D$ (De Sica) e Obsessâo (Visconti) ilustrariam a potência épico-realista em contraponto à montagem convencional do modelo dramático-clássico, pois a deambulaçăo da câmera năo se sujeitava totalmente à causalidade da açăo e à linearidade da montagem. Assim, o realismo como suposta potência decorrente da própria técnica cinematográfica teria se desenvolvido esteticamente em condiçōes históricas traumáticas (a Itália e a França no final da Segunda Grande Guerra, os cinemas novos do "Terceiro Mundo", etc.), nas quais as estratégias narrativas do modelo clássico-hollywoodiano náo podiam ser reproduzidas, tanto 
pela carência de meios técnicos, quanto pela necessidade de expressar plasticamente uma paisagem de destruiçâo e exploraçăo que náo poderia ser apagada ou sistematizada pela montagem padrâo. A "estética (ou Eztetyka) da fome" defendida por Glauber Rocha seria um dos desdobramentos dessa aposta na potência realista que, de modo geral, faria oposiçăo à transparência hollywoodiana, denunciando seu naturalismo ideológico por meio do uso deliberado de um tipo precário de filmagem, capaz de perturbar e desestabilizar, năo colocando a realidade filmada como puro cenário da encenaçăo dramática convencional, geralmente centrada no melodrama pequeno-burguês. A miséria do terceiro mundo, o subdesenvolvimento brasileiro, elaborado em forma e conteúdo, teria imposto ao Cinema Novo a necessidade de propor um novo tipo de realismo social:

O que fez do Cinema Novo um fenômeno de importância internacional foi justamente seu alto nível de compromisso com a verdade; foi seu próprio miserabilismo, que, antes escrito pela literatura de 30, foi agora fotografado pelo cinema de 60; e, se antes era escrito como denúncia social, hoje passou a ser discutido como problema político. (ROCHA, 1981, p. 30)

Em suma, observando de modo mais abrangente, poderíamos recuperar a tese de Fredric Jameson sobre as transformaçōes da imagem no decorrer do século XX ao afirmar que, em linhas gerais, essa prerrogativa política buscou afirmar um olhar crítico capaz de gerar a "visibilidade como colonizaçaăo" por meio da arte (JAMESON, 1994, p. 115). A partir desse olhar ("sartreano", nas palavras do autor), realizou-se uma literatura e um cinema utópicos que, dentre outras possibilidades, valeu-se do realismo como arma política durante as décadas de 1950 e 1960. Ainda segundo o crítico norte-americano, o que viria depois dessa "fase heróica" de resistência política, marcada pela luta anticolonial e pela virada contracultural, seria a resultante de um processo difuso de controle das produçôes culturais, cada vez mais administradas pelo mercado mundializado: um olhar novamente colonizado, agora administrado pela indústria cultural. A fusăo das esferas erudita e popular com as técnicas e narrativas da cultura de massa gerou uma amplificaçáo inédita de consumo de mercadorias culturais. Para Jameson, a partir dos anos 1970 dissemina-se, na arte, uma consciência resignada sobre a burocratizaçăo do olhar, um "olhar foucautiano" (op. cit., p. 118), que atravessa as produçôes artísticas, colocando o problema da imagem como uma forma de visáo/reconhecimento que apenas reproduz e dissemina uma estrutura rígida de poder: "Quando emergem as estruturas modernas do poder-saber, e se propagam pelo mundo através de visibilidade e visualidade, torna-se inútil postular a criaçăo de qualquer enclave de năo dominaçấo ou năo visibilidade como meta política" (op. cit. p 118).

As consequências desta perspectiva, como sabemos, foram observadas pelos situacionistas ao afirmarem que a imagem é a forma final de reificaçăo da vida social, que se transforma em mercadoria para consumo indiscriminado das massas. A sede de realidade convertida em um "resumo simplificado do mundo sensível" (DEBORD, 1997, p. 188), a partir do qual é possível justapor qualquer imagem uma a outra sem o perigo de se revelar as contradiçóes fundantes da sociedade. Contudo, a crítica ao espetáculo das imagens foi, paulatinamente, se convertendo em certa constataçâo conformista que já nâo apostava em nenhuma forma de resistência capaz de fazer oposiçấo ao mundo construído e administrado pelo simulacro (a obra de Jean Baudrillard seria 
paradigmática na pós-modernidade). Por fim, para fixarmos a tese de Fredric Jameson sobre a imagem na pós-modernidade, estaríamos em um momento histórico em que o próprio olhar teria sido domesticado a tal ponto que teríamos passado a nos comprazer com as próprias reproduçôes mecânicas e serializadas das imagens oriundas da indústria cultural. Nesta perspectiva, o fazer artístico teria em boa medida se limitado a reproduzir esse deslumbramento diante das imagens por meio do pastiche, da representaçăo galvanizada de um passado idílico (filmes de nostalgia e novo romance histórico, por exemplo), ou da reelaboraçăo das técnicas narrativas da cultura de massa em um momento em que toda a cultura se sujeita à condiçâo de mercadoria valiosa, sobretudo no cenário econômico desenhado pelo capitalismo pós-industrial. A condiçăo pós-moderna seria, segundo Jameson, marcada por uma resignaçâo política, na medida em que a crença na obra de arte como forma de conhecimento e transformaçăo da realidade teria sucumbido em definitivo: "se toda a realidade tornou-se profundamente visual e tende para a imagem, entâo, na mesma medida, torna-se cada vez mais difícil conceituar uma experiência específica da imagem que se distinguiria de outras formas de experiência" (JAMESON, 1994, p. 121).

Seguindo esse percurso histórico, poderíamos peremptoriamente considerar o realismo como uma forma estética que teria se tornado incapaz de remeter aos problemas colocados pela pós-modernidade ou, pior, apenas como um engodo rentável, uma técnica de relato bem adaptada às demandas da própria indústria cultural. Afinal, a cultura de massa tornou-se cada vez mais capaz de explorar por meio de narrativas degradadas e mistificadoras (biografias, filmes de nostalgia, reality shows, reportagens, etc.) um público sedento por alguma forma de experiência significativa em um mundo cada vez mais atomizado e hostil a interpretaçóes universalizantes. Tais conclusôes, no entanto, desconsideram as contradiçōes que toda forma estética assume ao resistir em um momento histórico que aparentemente lhe é extemporâneo. Dessa maneira, cabe observar que o realismo contemporâneo, tal qual pretendemos apontar em Aquarius, pode ainda suscitar possibilidades de resistência política e alto índice de criatividade estética, embora também possa ser frequentemente assimilado, sem maiores dificuldades, pelas ideologias dominantes e seus veículos midiáticos de comunicaçáo (como temos visto acontecer com boa parte da literatura e do cinema brasileiro mais recente). Em suma, poderíamos afirmar que a resistência política em uma obra supostamente realista passaria náo mais pela afirmaçăo de um olhar periférico (anticolonial, anticapitalista, marginal, minoritário, etc.), mas pelos pequenos curtos-circuitos dentro da própria fabulaçâo ideológica administrada pela indústria cultural, para quem a exploraçăo de efeitos de real tornou-se um imperativo gerador de audiência e lucro.

\section{Aquarius e o realismo: tensão, conflito social e a jornada problemática da heroína}

E como tal curto-circuito poderia ser vislumbrado em uma obra como Aquarius, supostamente realista? Em nossa hipótese, será a capacidade de fazer um uso peculiar da tensâo narrativa que produzirá tal possibilidade. Tensâo que pode ser percebida primeiramente na açăo dramática, mas que será também observada no próprio plano de expressáo, atingindo um efeito de estranhamento na enunciaçấo. Comecemos 
observando o conteúdo. A narrativa possui, em síntese, o seguinte argumento: temos Clara, uma personagem sexagenária, pertencente à classe média alta de Recife, que se recusa a vender seu apartamento para uma construtora interessada em derrubar o prédio e construir, naquele lugar, um edifício "moderno", dentro dos moldes da indústria imobiliária voltada para clientes de alto padrâo financeiro, na orla de Boa Viagem. Em princípio, ao querer preservar o local onde vive, as lembranças familiares que ali estâo inscritas, Clara entra em conflito năo só com a construtora, mas com outros atores sociais que lhe săo próximos: amigos, filhos, vizinhos, entre outros. A personagem enfrenta, de algum modo, o peso trágico de lutar contra forças muito maiores que as suas, năo mais reconhecidas como um fado imposto pelos deuses (como na tragédia antiga), mas como sendo, no contexto contemporâneo, a força onipotente do mercado. O papel prescrito a ela seria o de ser uma cliente V.I.P., levando uma vida confortável e segura no novo edifício a ser construído especialmente para pessoas de sua própria origem social. Por conseguinte, o nome do edifício, "Aquarius", faz-se uma metáfora mais geral da sensaçấo de aprisionamento vivenciada pela protagonista e, conforme pretendemos apontar, também sentida pelo espectador, a partir do modo de se enquadrar, em perspectiva, a própria Clara em relaçăo ao espaço que a rodeia. Em muitas cenas, vemos a protagonista sendo colocada em primeiro plano, mas observada entre os vidros e paredes do apartamento, reforçando, pela profundidade de campo, o enclausuramento da personagem.

\section{Figura 1 - Clara em seu apartamento (26:58 $\mathrm{min})$}

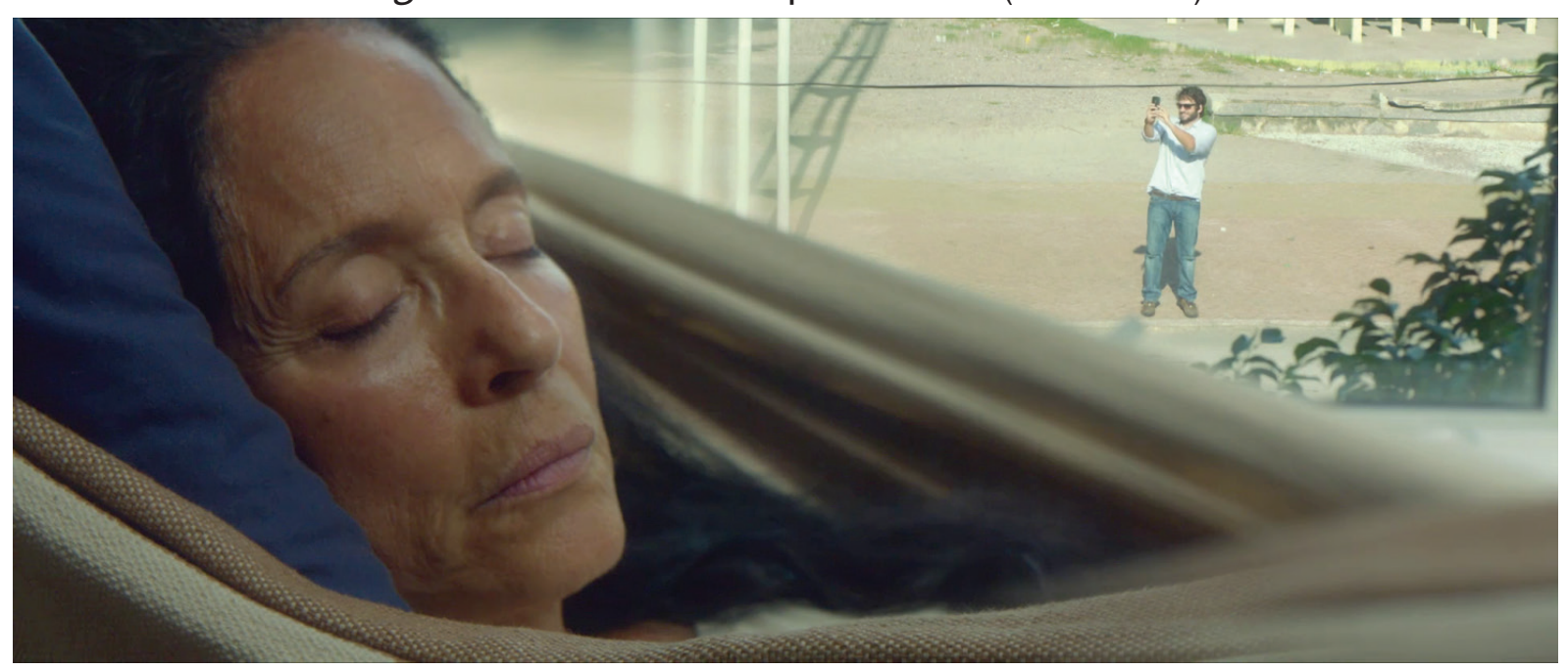

Fonte: AQUARIUS, 2016, 26:58 min

Há, no entanto, uma dualidade nessa clausura: ao mesmo tempo em que notamos os limites espaciais e sociais sutilmente impostos a Clara (lembremos que até o banho de mar lhe é vigiado e tolhido por meio dos cuidados de Roberval, o bombeiro salva-vidas com quem possui amizade), observamos uma dedicaçăo voluntária da personagem para dar vida e beleza ao próprio cenário de seu aprisionamento. $O$ aquário expressa, como metáfora, a ideia de um espaço transparente no qual uma forma de vida resiste: quem o vê de fora, pode contemplá-lo com curiosidade, reconhecer-lhe uma forma de beleza; quem está dentro, vive a sensaçăo de estar preso, observado, porém relativamente seguro. A câmera que percorre em planos longos os discos de vinil, os móveis, os quadros, os álbuns fotográficos, entre outros objetos do apartamento, conduz o espectador 
(enunciatário pressuposto) a manter um olhar sob constante tensâo, alimentada pela ambiguidade de reconhecer o aprisionamento da personagem e, por outro lado, sentir-se confortável diante de um espaço bem cuidado. Assim, temos a apresentaçáo de um cenário aconchegante, capaz de produzir uma empatia afetiva ou mesmo um deslumbramento por parte do espectador, que tem seu olhar estimulado pela câmera em movimento. No entanto, ao mesmo tempo, o próprio espaço delineia os limites impostos à vida solitária de Clara, como uma fronteira que passará a ser questionada cada vez mais, a partir dos ataques in crescendo dos homens da construtora e das outras personagens cobrando-lhe a saída.

Desta forma, há um agente destrutivo que se lança contra o pequeno mundo de Clara. Um câncer que se alastra pelo aquário/apartamento, afetando também o seu ser/corpo. As investidas da construtora contra a personagem, sobretudo nas cenas em que o jovem engenheiro Diego tenta cinicamente convencer Clara a sair do prédio, assim como o cupinzeiro colocado no andar superior do edifício para minar a estrutura, săo a figurativizaçáo mais óbvia desse câncer. Contudo, há uma conotaçăo mais profunda que, podemos dizer, eleva a jornada da heroína a uma dimensâo trágica: o embate de Clara contra uma "doença" social generalizada, uma for ça intangível, capaz de agredi-la das mais diversas formas: o próprio processo de reificaçăo da vida social. A constataçăo de que as relaçóes humanas, as recordaçôes e os afetos estáo submetidos a uma lógica mercantil, contra a qual parece inútil esbater-se, eleva Clara a uma atuaçăo trágica, com um pathos definido: querer afirmar valores náo-quantificáveis em um mundo que transforma coisas e seres em mercadoria. É com essa marca fundamental de caráter que o espectador se identifica. ${ }^{3}$ Ainda que rapidamente, convém recuperar o conceito de reificaçâo, a partir da formulaçăo teórica de Georg Lukács, a fim de compreender as suas implicaçōes nâo só no filme, mas também nas possibilidades de representaçăo artística que foram sendo articuladas desde o final do século XVIII, a partir da ascensáo da burguesia como classe fundamental:

As determinaçôes mercantis, [...] aparecem na consciência do homem e da sociedade burguesa, como formas puras, verdadeiras e autênticas do capital. Para a consciência reificada, essas formas de capital se transformam necessariamente nos verdadeiros representantes da sua vida social, justamente porque nelas se esfumam, a ponto de se tornarem completamente imperceptíveis e irreconhecíveis, as relaçôes dos homens entre si e com os objetos reais, destinados à satisfaçăo real de suas necessidades. Tais relaçôes sâo ocultas na relaçăo mercantil imediata. (LUKÁCS, 2003, p. 211)

Em linhas gerais, é importante compreender o processo de reificaçăo social como um tema fundamental das artes desde a consolidaçâo da modernidade liberal, na medida em que, no caso da narrativa literária, tratou-se de representar epicamente pelo romance, desde Dom Quixote e depois com os românticos

3 Lembremos que, na teoria aristotélica, o pathos do herói também pressupôe uma identificaçâo (empatia) com o espectador, que é levado a desejar que o protagonista vença as adversidades, ainda que no fundo ele saiba que isso nâo seja possivel. Trata-se, portanto, de "uma comoçấo espontânea, sem necessidade de conscientizaçâo de sua origem ou finalidade. [...] O homem patético é levado pelo que deve ser e seu arrebatamento investe contra o status quo" (STAIGER, 1997, 65) 
e realistas, "um mundo abandonado por Deus" (LUKÁCS, 2000, p. 60), no qual o herói problemático, ao buscar afirmar valores na jornada, acaba por perceber que tais valores soçobram diante do pragmatismo de uma sociedade movida pelo interesse econômico (lucro). Embora Lukács tenha feito uma tardia e controversa defesa do realismo como a forma mais eficaz e objetiva de representaçâo do decadentismo burguês, podemos dizer que a própria intensificaçâo do processo reificante passou a demandar outros registros narrativos muito além do realismo tradicional e da representaçăo de um herói problemático:

Com o passar do tempo, à medida em que a reificaçâo foi fazendo progressos, a ruptura entre a realidade social e a busca do humano acentuou-se a tal ponto - pelo menos no mundo capitalista - que a expressâo dessa busca teve que dar lugar à simples constataçâo e descriçăo de uma realidade social reificada inumana e privada de significaçăo. (GOLDMANN, p. 07)

Se na literatura, o romance, no decorrer do século XX, explorou uma narratividade focada na experimentaçâo com a linguagem, na fragmentaçâo do narrador e na náo admissâo de personagens sujeitas à causalidade psicológica ou de cunho naturalista (problematizando a "tipificaçăo" objetiva definida por Lukács), o cinema, de modo geral, valeu-se das regras narrativas do romance realista do século XIX para consolidar sua linguagem. ${ }^{4}$ Assim, embora o experimentalismo modernista tenha sido recuperado e desenvolvido pelo cinema em diversos momentos e escolas (Expressionismo Alemáo, Cinema Soviético, Nouvelle Vague, Cinema Novo e Marginal no caso brasileiro, etc.), cabe ressaltar que o realismo manteve o predomínio entre as formas de representaçăo cinematográfica, tanto nos filmes mais comerciais (afeitos às peripécias, à causalidade, tensâo e agilidade narrativa do folhetim novelesco do século XIX), como nos chamados "dramas", de ritmo mais lento e com maior desenvolvimento psicológico das personagens.

Em nossa perspectiva, é importante recuperar esse percurso histórico das formas narrativas, ainda que brevemente, observando seu desenvolvimento da modernidade à pós-modernidade, porque nos permite compreender, de alguma forma, que o realismo em Aquarius responde a uma longa tradiçăo representativa que remete à oposiçâo semântica fundamental entre reificaçâo (valor de troca) X humanizaçâo (valor de uso). Como exemplo, podemos pensar em várias cenas que figurativizam esse eixo temático: uma delas dá-se quando Clara recebe, em seu apartamento, duas jornalistas que vêm entrevistá-la e perguntar sobre seu prestigiado trabalho como crítica musical. Inicialmente a repórter pergunta se Clara, que escreveu um livro importante sobre Heitor Villa-Lobos, também ouve música em formato digital. Ao invés de responder à questăo, ela prefere contar uma história sobre um disco de John Lennon que comprara em um sebo de Porto Alegre. Nesse álbum (Double Fantasy), encontrara oculto no encarte um artigo publicado em um jornal semanas antes de John Lennon ser assassinado em 1980.

Recuperando a leitura história de Sergei Eisenstein, a montagem cinematográfica derivaria diretamente da técnica narrativa romanesca do século XIX, desenvolvida por escritores como Charles Dickens, sendo reelaborada pelo cineasta D. W. Griffith nas primeiras décadas do século XX, tornando-se fundamento do padrăo clássico. Cf.: EISENSTEIN, 2002). 
Ao valorizar o título do artigo "Os Planos de John Lennon para o Futuro", Clara vê na compra do disco uma experiência autêntica, pois o objeto porta um valor de uso que define uma relaçăo afetivo-cognitiva para além do mero ato de comprar um objeto, uma "mensagem na garrafa" (em suas palavras), capaz de trazer um significado especial dentro do consumo padronizado de produtos culturais. Um disco de vinil, de alguma forma, ao passar por várias máos, gerou uma mensagem que transcendeu sua reprodutibilidade técnica, como algo que foi manuseado, tocado em sua constituiçăo física, diferentemente da codificaçăo abstrata dos suportes digitais. Contudo, a "história" de Clara năo é registrada pela repórter, que insiste em saber se Clara também gosta de ouvir músicas na mídia digital. A manchete, saberemos depois, sairá acompanhada de uma foto de Clara e do título "Eu Gosto de MP3". A informaçâo vendável é aquela que já está formatada em esquemas de comunicaçăo que visam ressaltar algo polêmico, porém premeditado: uma crítica musical da velha guarda que também gosta de ouvir música digital. É a apologia sensacionalista da novidade superando o antigo, convertida em informaçăo clichê, altamente aceitável e vendável. Outras cenas poderiam ser recuperadas, como a visita inesperada dos filhos de Clara que, vendo a valorizaçáo do apartamento por conta da resistência dela em sair, tentam convencê-la a vender o imóvel. Para eles, o espaço afetivo da infância, registrado nas primeiras cenas do filme e nas fotos que Clara insiste em mostrar aos parentes, é convertido em puro signo de valor econômico. Lembremos que a filha de Clara, Ana Paula, em outra cena, nem sequer reconhecerá a pintura nova que a máe manda fazer na fachada do prédio. A filha, com dificuldades financeiras, vê o espaço e, de certa forma, a própria relaçăo com măe, como mera coisa (res) ${ }^{5}$ a ser apropriada para alguma forma de lucro pessoal.

Mas o ponto em que a tensâo crítica se estabelece de modo mais evidente é quando Clara vivencia, em seu íntimo, o dilema de sujeitar ou náo seus próprios desejos e afetos à lógica mercantil. A reificaçăo torna-se componente de uma crise subjetiva, embora esta năo revele qualquer apelo melodramático. Na segunda parte do filme, intitulada "O Amor de Clara", evidencia-se a vida solitária da personagem, calcada em recordaçóes, cançóes e fotografias antigas, poucas amizades (o sobrinho, o bombeiro salva-vidas, conversas rápidas com amigas de meia-idade). Ao saber que uma amiga teria contratado um profissional do sexo para atendê-la, Clara, após flertar e se sentir rejeitada por um homem que conhece casualmente (ele se afasta ao perceber a cicatriz no peito da protagonista, pois, no passado, ela vencera um câncer por meio de mastectomia), decide também contratar tal serviço. Importa considerar que esta decisăo vem após ela assistir, de modo voyeurístico, empregados da construtora realizando uma orgia no andar superior do prédio. $\mathrm{O}$ olhar de Clara, demorando-se sobre a cena entrevista pela fresta da porta semiaberta, desdobra-se em uma expressáo facial, em close up, revelando curiosidade e satisfaçăo. Se a "festa" foi premeditada, buscando assustar e incomodar Clara - já que objetivamente os donos da construtora querem expulsá-la com urgência -, nota-se que a protagonista, ao contrário do que se esperava, sente-se até mesmo atraída pela performance sexual dos envolvidos. Os corpos excitados săo focalizados por uma câmera subjetiva, vendo-se rápida e parcialmente a orgia pela

Radical da palavra "reificaçăo". 
fresta da porta. Pela câmera subjetiva, a visăo de Clara identifica-se ao olhar do espectador no plano enunciativo. Ambos atraídos pela visáo da cena explícita de sexo grupal. A imagem erótica, motor da indústria cultural, afeta o espectador da mesma forma que a personagem é afetada. Como consequência, render-se provisoriamente às estratégias desse comércio de desejos năo parece ser tăo pernicioso, já que ao menos se pode afirmar uma forma de sensibilidade, nem que seja como visada/miragem ou, de modo mais radical, como contato físico mediado pela troca mercantil. Ao envolver-se com o garoto de programa, Clara enfrenta sua solidăo e os seus próprios desejos com as armas que sua própria classe social possui: comprar. Tanto coisas, quanto pessoas. Embora Clara interaja de modo compassivo e amistoso com os trabalhadores, com os que lhe prestam serviço (a empregada Ladjane, o porteiro, os pedreiros, o próprio "amante profissional" etc.), resta sempre uma tensăo que perpassa as cenas, uma tensâo entre as classes sociais, afinal, independentemente das boas maneiras, há um relacionamento de dominaçâo e sujeiçăo que se imprime em cada "trabalho" remunerado. Tensâo que se exacerba quando certas imagens assustadoras desnudam suas fantasias de classe: temos o sonho de Clara, no qual uma empregada negra rouba suas joias; o medo de ter sido assaltada pelo amante contratado, após terem feito sexo e ela ter se embriagado. Tensăo que se mostra sutil quando pensamos na indiferença mal disfarçada que Clara e o sobrinho, Tomás, manifestam pela morte do filho de Ladjane, morto em um acidente de trânsito. Ainda que cumpram o protocolo de ir visitar a casa da empregada e celebrar o aniversário do filho morto, suas preocupaçôes e suas dores săo outras. Obviamente, năo se trata de observar uma hipocrisia radical no comportamento de Clara, mas antes compreender como o seu perfil de heroína clássica (determinada, à busca de um objeto-valor que lhe acentua valores morais sólidos) é contraposto sutilmente a uma tipificaçăo social de cunho conservador. A solidariedade de Clara para com os mais pobres convive com um ar aristocrático/paternalista, recuperando de alguma forma a tese de Gilberto Freire em Sobrados e Mocambos, na qual se descreve como os traços paternalistas da elite colonial-brasileira persistiram na configuraçăo da burguesia urbana a partir do século XIX (FREYRE, 2006). Embora nâo seja oriunda de uma família da elite tradicional nordestina - lembremos a cena em que o engenheiro Diego ironiza a origem da protagonista, dizendo que a respeitava por ter vencido na vida, mesmo sendo de "família de pele mais morena" - , Clara conquistou um lugar próximo à classe dominante e o filme nos mostra sutilmente como essa ambiguidade se apresenta na caracterizaçăo da protagonista.

Nesse sentido, o sonho que Clara tem com a empregada de sua infância parece quase uma revelaçăo, ao mesmo tempo em que reforça essa solidariedade tensa entre dominante/dominado: Juvenita, enquanto rouba as joias no quarto de Clara, aponta para ela e mostra que o peito da patroa está sangrando. Assim, na última parte - intitulada "O câncer de Clara" -, é a empregada que, em sonho, revela o que está acontecendo à protagonista: uma doença a está devorando, os cupins do último andar do prédio, como um câncer implantado pelos antagonistas, estâo roendo a estrutura que a sustenta. Em seguida, dois empregados da construtora que adquiriram simpatia por Clara (a qual sempre os chamava pelo nome próprio), avisam-na que há um grave problema no último andar do prédio. Assim, tanto o sonho com a empregada, quanto a informaçăo dada pelos empregados, reforçam a tese de que pode haver uma estratégica colaboraçáo entre classes sociais, uma conciliaçăo tensa, mas possível. A protagonista obviamente 
năo é uma ilustraçăo da tese de Gilberto Freyre (op. cit.), mas é importante considerar que o conteúdo fílmico parece apontar certa utopia social conservadora ao supor um acordo relativamente amistoso entre as classes, gerando uma identificaçăo do espectador com o pathos de Clara e sua tentativa individual de revestir as relaçóes interpessoais com afeto e honestidade, recuperados de um passado de recordaçóes que a alimenta. Todavia, o que nâo permite a elaboraçăo cabal de um registro melodramático, orquestrado pela voz de uma heroína clássica, é justamente a tensāo dramática, conforme já salientamos. Na medida em que a grandeza de caráter de Clara entra sempre em conflito com o espaço simbólico, com um mundo social que năo se dá a ver em sua inteireza, gera-se uma frustraçăo de expectativas quanto a uma revelaçăo das coisas, restando sempre algo oculto que a câmera năo mostra diretamente: um mal-estar social, sutilmente esboçado nos gestos, nas expressóes e repercutido nos sons do ambiente registrado ${ }^{6}$. Nesse sentido, cabe ainda tecer mais algumas consideraçóes sobre os usos da tensâo na narrativa e seus efeitos sobre o espectador no plano enunciativo.

\section{Contra o estereótipo: implicações políticas e utópicas do realismo tenso}

A tensăo como elemento central da poética de Aquarius pode ser compreendida também a partir um processo de diluiçăo do conflito central: a disputa entre Clara e a construtora pela posse do apartamento vai se alastrando pelo ambiente, disseminando-se nas relaçôes familiares, nas amizades, no trato cotidiano com os prestadores de serviço, podendo até ser atenuada, como nos momentos em que Clara ouve música (as cançôes no filme servem como contraponto claro à reificaçăo social). Contudo, mesmo em momentos de maior descontraçâo (lembremos também da sequência em que Clara sai com as amigas para conversar e dançar), a câmera em movimento registra sempre uma expressâo mais grave de algum personagem ou algum gesto estranho que năo permite que a tensâo arrefeça. A força que impele Clara a sair do apartamento, tentando subjugá-la, năo resulta apenas de uma vontade expressa dos antagonistas tradicionais (os donos da construtora). Essa força, podemos dizer, está dispersa no espaço simbólico, podendo ser pressentida, mesmo quando năo se faz notória. Assim, podemos afirmar que há uma sofisticada projeçấo enunciativa da tensáo dramática que implica, por fim, em um desnudamento, por antecipaçâo, de estereótipos narrativos que povoam o imaginário do espectador contemporâneo.

A fim de compreender essa projeçâo enunciativa da tensăo, convém expandir um pouco mais a reflexăo teórico-terminológica. De início, é preciso compreender o conceito de tensấo como um efeito que năo diz respeito apenas ao conflito que a açăo encerra; a tensấo pode ser concebida, antes de tudo, como o resultado de um processo de encadeamento da açấo dramática que tende para um fim que tudo explica, numa necessidade imperiosa de fazer cada cena/ato ser um desdobramento parcial e uma pista da verdade que deverá emergir no final da narrativa. Destarte, A tensăo seria o efeito que se consegue ao se instituir uma ansiedade durativa na enunciaçăo, a partir do momento em que cada parte tende para um fim, năo tendo valor por si mesma:

$6 \quad$ Parece-nos que tal efeito foi ainda mais intenso no filme anterior de Kleber Mendonça Filho, O Som ao Redor. 
Se ele [o estilo dramático] procede mais problematicamente, consegue a tensăo. Criase essa tensâo graças à interdependência das partes. Nenhuma parte se basta, nem basta ao leitor. Necessita sempre de complementaçăo. A próxima parte também năo é bastante, gera uma nova questăo, exige novo complemento. Somente no fim năo falta mais nada, satisfaz-se à impaciência. (STAIGER, 1997, p. 69)

Assim, a tensâo seria a estratégia fundamental de um constructo narrativo no qual uma situaçăo problemática é apresentada e desenvolvida, mas termina por ser superada e encerrada em uma soluçấo que explica tudo o que foi encenado/mostrado no percurso narrativo. A regra da "espingarda na parede" seria obviamente a ilustraçáo desse modelo aplicada ao realismo clássico, sobre o qual a montagem griffithiana se constituiu, lançando as bases da narratividade hollywoodiana. Conforme nos lembra David Bordwell, a linearidade do padrâo cinematográfico clássico advém desse uso da tensấo como aquilo que cria nexos de causalidade na sequência das cenas que se conectam em prol de uma explicaçâo totalizante e abstrata:

No curso de sua açáo, a cena clássica prossegue ou conclui os desenvolvimentos de causa e efeito deixados pendentes em cenas anteriores, abrindo, ao mesmo tempo, novas linhas causais para desenvolvimento futuro. Uma linha de açăo, ao menos, deve ser deixada em suspenso para servir de motivaçăo a próxima cena, que retoma a linha deixada pendente. Daí a famosa "linearidade" da construçấo clássica. (BORDWELL, 2005, p. 282)

Podemos dizer, portanto, que no uso convencional da tensâo há uma sujeiçấo da imagem a uma causalidade dramática que, no fim das contas, condiciona a percepçáo do espectador ao mero reconhecimento de imagens sensório-motoras codificadas na montagem em prol da açâo dramática. No modelo padronizado, o espectador é estimulado a ver apenas o desenvolvimento da fábula por meio de uma tensăo que lhe vende a expectativa de que tudo será explicado ao final. Cabe destacar, assim, que a tensâo cinematográfica, em seu uso mais banal, é o efeito que nos priva de um aprofundamento sobre o que é mostrado, lançando cada imagem e cada cena em uma sucessáo estereotipada de eventos que se sujeita a uma estrutura lógico-abstrata. Ao criticar o que chama de "imagem-açăo" no cinema hollywoodiano, Deleuze afirma:

Um clichê é uma imagem sensório-motora da coisa. Como disz Bergson, nós năo percebemos a coisa ou a imagem inteira, percebemos sempre menos, percebemos apenas o que estamos interessados em perceber, ou melhor, o que temos interesse em perceber, devido a nossos interesses econômicos, nossas crenças ideológicas, nossas exigências psicológicas. Portanto, comumente, percebemos apenas clichês. (DELEUZE, 2005, p. 31)

Cabe aqui, portanto, indagarmos se é possível um uso da tensăo na arquitetura narrativa que possa, a contrapelo, assumir uma dimensăo estético-progressista e náo recair nos limites conservadores da imagem-açâo. Assim, é observando as nuances da forma estética, e năo simplesmente seu conteúdo, que podemos avaliar em que medida uma obra pode ser de fato política e esteticamente progressista. Partindo desse raciocínio, a força de Aquarius nâo está alocada simplesmente em seu conteúdo narrativo, no qual vemos uma personagem lutar com bravura contra os ditames do mercado e vivenciar problematicamente as agruras 
da reificaçấo social, na medida em que busca humanizar as coisas e pessoas ao redor ("mostra que tu é intenso", ela diz ao sobrinho Tomás, apresentando-lhe um disco de Maria Bethania). Já vimos que, em boa medida, Clara é também uma personagem típica que apresenta também traços conservadores, presa a um passado que, de algum modo, é visto como um bem perdido que a memória recupera e enaltece. Se o espectador se identifica empaticamente com a heroína, poderíamos, inclusive, discutir o quăo pernicioso poderia ser esse saudosismo conservador, bem como a conciliaçấo de classes referida anteriormente. No melhor dos casos, poderíamos apenas reconhecer o esforço utópico do filme em repropor uma requentada resposta social-democrata em tempos de grave crise econômica e social: se nossa classe média e nossa elite fossem mais "humanas" e compassivas (como Clara é), se o mercado especulativo fosse barrado (como um câncer/cupinzeiro a ser combatido), as tensôes sociais poderiam ser menores, menos violentas, sem que necessariamente a hierarquia social se alterasse drasticamente. Tal leitura, focada apenas no conteúdo narrativo, seria insuficiente para reconhecer a potência estética de Aquarius. Contudo, ao nos voltarmos para a forma fílmica, observaremos que sua força reside na tensâo que se projeta na enunciaçâo, desconstruindo a imagem-açâo e suas expectativas estereotipadas. Voltemos a percorrer algumas cenas, mas observando os efeitos de tensáo no plano de expressáo.

Uma cena muito emblemática dessa projeçâo da tensâo no plano enunciativo é a que temos Roberval e Clara participando de uma sessáo de "terapia do riso", realizada ao ar livre, na praia de Boa Viagem. Nessa cena, a câmera filma, de cima, o grupo que está fazendo o exercício e, depois, filma o professor, em contra-plongée, dando os comandos para que todos pratiquem o riso coletivo. $O$ estranhamento dá-se pelo registro em primeiro plano dos corpos fazendo um esforço exagerado para conseguir rir. Em seguida, vemos alguns jovens negros se aproximando do grupo. A montagem paralela, acelerando os planos, alimenta uma tensăo na enunciaçăo, pois remete à expectativa de que aqueles jovens negros, possivelmente da periferia, poderiam criar tumulto ou até mesmo assaltar os participantes da sessâo. Contudo, tal expectativa é frustrada, pois os jovens apenas se deitam junto dos outros e passam a realizar o exercício. No entanto, a sensaçăo de temor é forte entre os participantes, pois as risadas cessam e as expressōes faciais demonstram preocupaçăo. A cena encerra com o professor dizendo: "respeito... continua... respeito, seriedade" (MENDONÇA , op. cit., 21:08 min). O nervoso riso coletivo é, de certa forma, uma riso que se dirige ao próprio espectador, pois ele de algum modo foi ludibriado, pois sofreu uma quebra de expectativas (o que é um recurso fundamental para se gerar o efeito cômico). Importa considerar que esta cena, em princípio, aparentemente năo serve diretamente ao conflito central da trama: a luta de Clara contra a construtora ou, na estrutura profunda, o embate entre a vida autêntica (valor de uso) X vida reificada (valor de troca). Contudo, o impacto visual da cena aponta um aspecto fundamental no filme: gerar estranhamento a partir da sugestăo/induçáo a estereótipos que estamos acostumados a ver no cinema e na televisăo. 
Figura 2 - Clara e Roberval em sessão aberta de terapia do riso (20:57 min)

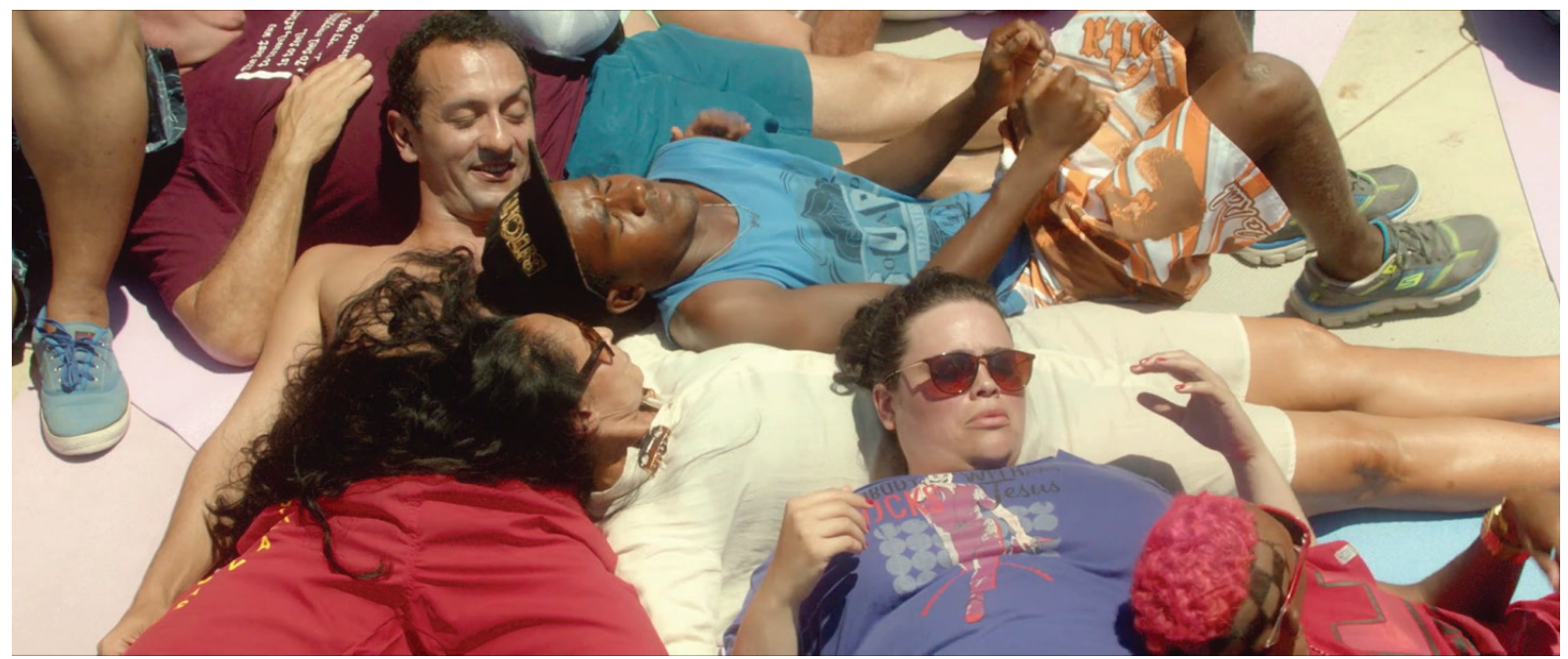

Fonte: AQUARIUS, 2016, 20:57 min.

Outras cenas podem ser lembradas, ainda que rapidamente, como exemplo desse procedimento de gerar tensáo no plano enunciativo e frustrar expectativas do espectador: no início do filme, vemos um carro rodando na praia e imaginamos que aqueles jovens praticarăo alguma contravençăo. Contudo, eles apenas estăo indo para uma festa de família e param para ouvir uma cançăo da banda Queen. A próxima cena, a festa de aniversário de tia Julia, năo é diferente: o espectador espera que a tia já idosa fique comovida com as homenagens, contudo, a câmera mostra uma cena de sexo oral sobre um dos móveis da sala, revelando uma antiga lembrança da tia, junto de seu amante. A câmera percorre os rostos na festa e notamos que há um mal-estar discreto que afeta o andamento da açâo. Em outra cena, vemos dois empregados da construtora (Josimar e Rivanildo) se aproximarem furtivamente de Clara, na entrada do portăo. Pela expressâo grave e alterada de ambos, e pela câmera que acompanha Clara de longe, assemelhando-se ao procedimento convencional de identificar o campo de visăo com o olhar do facínora que observa a vítima antes do ataque (thriller de suspense), o espectador tende a imaginar que Clara poderá sofrer algum mal. Ao contrário, logo se percebe que os empregados vêm ajudá-la, informando sobre o cupinzeiro que foi colocado criminosamente no último andar do prédio. Em contrapartida, na cena em que o engenheiro Diego e seu pai, dono da construtora, fazem a primeira visita a Clara, ambos se mostram tăo gentis que, em princípio, o espectador tende a năo ver risco naqueles senhores bem apessoados. O momento cômico, no qual a proposta da empresa é reiteradamente posta debaixo da porta e, em seguida, posta pra fora por Clara, apenas reforça essa sensaçăo de que os engenheiros nâo oferecem perigo, afinal, săo sorridentes, sutis e até mesmo cordatos. Aos poucos, vai-se compreendendo que, diferentemente do que se supunha, ambos podem ir às últimas consequências para assediar, intimidar e ameaçar a protagonista.

Várias outras cenas poderiam ser recuperadas para observar esse jogo entre gerar tensâo no plano enunciativo e frustrar o espectador quanto à realizaçăo do que foi previamente articulado. Contudo, importa apenas destacar como Aquarius tece a possibilidade de provocar um estranhamento que visa, justamente, a desnudar o estereótipo 
pela sua năo concretizaçăo. Aquilo que o espectador espera ver, desde a imagem negativa de um tipo social (sobretudo, os trabalhadores e marginalizados), uma açáo violenta (confronto direto), o melodrama romântico (o homem que conhece no baile), o lado maternal de Clara (a relaçăo com os filhos e com o neto), entre outros, nâo se realiza integralmente. A tensăo, ao invés de apenas encaminhar a açăo para a resoluçăo do conflito e para um fim que tudo explica, volta-se contra o próprio desejo inconsciente do enunciatário em ver realizado o estereótipo. A cada cena, uma sequência possível desaba aos olhos do espectador. Por isso, a cena final, enquanto situaçáo-limite ${ }^{7}$, encerra-se com o cupinzeiro sendo lançado na mesa do escritório da construtora. Náo há continuaçăo: apenas o cupinzeiro como última imagem de um sistema carcomido. Se os antagonistas serăo punidos ou se Clara vencerá a disputa judicial, năo importa, apesar de o espectador aguardar o confronto final, que náo acontece. Nesse aspecto, o realismo de Aquarius está muito além da narrativa esquemática, da crença ingênua na representaçăo objetiva da vida em sociedade e nem mesmo se lança em um aprofundamento psicológico dos personagens (como nos "dramas" pretensamente denominados "cinema de arte"). Seu realismo está imbuído de um imaginário midiático que, a cada momento, é posto sob tensăo pela expectativa de ver realizado o estereótipo, que náo se concretiza. Aqui, vemos que Aquarius dialoga com uma tradiçâo cinematográfica que buscou denunciar o olhar reificado que a indústria cultural e suas narrativas constroem, um tipo de cinema que soube lidar com o espetáculo e fazer-lhe concomitantemente a denúncia, pelo menos desde Cidadâo Kane, de Orson Welles, e Janela Indiscreta, de Alfred Hitchcoch. No contexto contemporâneo, o realismo tenso muitas vezes parece se aproximar de um thriller de suspense, mas năo avança como o esperado (como no brilhante e pouco conhecido filme $O$ Homem ao Lado (2011), dirigido pelos argentinos Mariano Cohn e Gastón Duprat). A ambiguidade da imagem, a breve suspensăo da açăo em prol da situaçăo e a nâo realizaçăo do estereótipo, produzem um impacto estético e político que denuncia também a reificaçăo presente no imaginário coletivo, as nossas expectativas prévias, bem administradas pela mídia hegemônica. Nesse sentido, o filme faz a aposta política de desnudar a reificaçăo social começando pela própria conscientizaçấo do espectador a respeito de seu olhar reificado. 0 impacto político de Aquarius consiste, portanto, em contar uma história pelo viés realista, mas denunciando a estereotipia das imagens que constroem a hegemonia ideológica de nossa época e que quer se apresentar como dado objetivo de realidade. Os estereótipos "nâo constituem erros de percepçăo, mas uma forma de controle social" (STAM, p. 289), por isso, quando a obra de arte contemporânea os incorpora e, ao mesmo tempo, desmascara-os em nosso próprio olhar, gera-se uma possibilidade de resistência.

Situaçăo-limite é a situaçăo dramática na qual a tensâo atingiu um grau tăo elevado ("limite") que o momento seguinte é de confronto. (CAMPOS, 2007, p. 87) 


\section{Referências Bibliográficas}

ADORNO, Theodor W. Posiçáo do narrador no romance contemporâneo. In: Notas de Literatura. Traduçăo: Jorge M. B. de Almeida. Săo Paulo: Duas Cidades; 34, 2003. v. 1, pp. 55-64.

BAZIN, André. O realismo cinematográfico e a escola italiana da liberaçăo. In: 0 Cinema: ensaios. Traduçăo: Eloisa de Araújo Ribeiro. Săo Paulo: Editora Braziliense, 1991. pp. 233-257.

BORDWELL, David. O cinema clássico hollywoodiano: normas e princípios narrativos. In: RAMOS, F. P. (Org.). Teoria contemporânea de cinema: documentário e narratividade ficcional. Sáo Paulo: Senac, 2005. pp. 277-301.

CAMPOS, Flávio de. Roteiro de cinema e televisáo: a arte e a técnica de imaginar, perceber e narrar uma história. Rio de Janeiro: Jorge Zahar, 2007.

COUTINHO, Carlos Nelson. Lukács, Proust e Kafka: Literatura e sociedade no século XX. Rio de Janeiro: Civilizaçăo Brasileira, 2005.

DEBORD, Guy. A sociedade do espetáculo e Comentários sobre a sociedade do espetáculo. Traduçáo: Estela dos Santos Abreu. Rio de Janeiro: Contraponto, 1997. EISENSTEIN, Sergei. Dickens, Griffith e Nós. In: __ (Org.). A forma do filme. Traduçăo: Teresa Otonni. Rio de. Janeiro: Jorge Zahar, 2002. pp. 176-224.

FREYRE, Gilberto. Sobrados e mocambos. 16. ed. Săo Paulo: Global, 2006.

GOLDMANN, Lucien. A reificaçăo. In: Janeiro: Paz e Terra, 1979. pp. 105-152. (Org.). Dialética e Cultura. 2. ed. Rio de JAMESON, Fredric. Transformaçôes da imagem na pós-modernidade. In: GAZOLLA, Ana Lúcia Almeida (Orgs.). Espaço e Imagem: teorias do pós-moderno e outros ensaios de Fredric Jameson. Traduçấo: Ana Lúcia Almeida Gazolla. Rio de Janeiro: UFR, 1994. pp. 115-144.

LUKÁCS, Georg. A teoria do romance: um ensaio histórico-filosófico sobre as formas da grande épica. Traduçâo: José Marcos Mariani. Săo Paulo: 34; Livraria Duas Cidades, 2000.

História e Consciência de Classe: estudos sobre a dialética marxista. Traduçâo: Rodinei Nascimento. Sáo Paulo: Martins Fontes, 2003.

NAGIB, Lucia. A utopia no cinema brasileiro: matrizes, nostalgia, distopias. Sâo Paulo: Cosac Naify, 2006.

ORICCHIO, Luiz Zanin. Cinema de Novo: um balanço crítico da Retomada. Săo Paulo: Estaçấo Liberdade, 2003.

PELLEGRINI, Tânia. Realismo: a persistência de um mundo hostil. Revista Brasileira de Literatura Comparada, n. 14, 2009.

ROCHA, Glauber. Eztetyka da Fome. In: Revoluçaáo do cinema novo. Rio de Janeiro: lhambra, 1981, pp. 28-32. 
SHOHAT, Ella; STAM, Robert. Crítica da imagem eurocêntrica. Trad. Marcos Soares. Săo Paulo: Cosac Naify, 2006.

STAIGER, Emil. Conceitos fundamentais da poética. Traduçăo: Celeste Aída Galeâo. 3. ed. Rio de Janeiro: Tempo Brasileiro, 1997.

XAVIER, Ismail. Do texto ao filme: a trama, a cena e a construçăo do olhar no cinema. In: PELLEGRINI, Tânia et al. (Orgs.). Literatura, cinema e televisăo. Săo Paulo: SENAC, 2003, pp. 61-89. 